\title{
Effect of Swimming Style and Nutritional Status on Asthmic Complaints
}

\author{
Ossy Ulfha Silvanny ${ }^{1 *}$, Sayuti Syahara ${ }^{2}$, and Bafirman ${ }^{3}$ \\ ${ }^{1,2,3}$ Dep. of Coaching, Faculty of Sport Science, Universitas Negeri Padang, Padang, Indonesia \\ *Corresponding author. Email: ulfasyukriahsy@gmail.com
}

\begin{abstract}
The problem in this study originated from asthma complaints suffered by elementary school students in Nanggalo Lapai Subdistrict, Padang City, such as SD Negeri 06 and SD Negeri 18, Nanggalo Lapai Subdistrict, Padang City. This causes, students have limitations in physical activity, fatigue, lack of enthusiasm, less ideal posture (tend to be a bit thin), and have below average academic value. This study aims to determine the effect of swimming style and nutritional status on asthma complaints of elementary school students in Nanggalo Lapai Subdistrict, Padang City. This type of research is an experiment with factorial design by level $2 \times 2$. The population in this study were all students of SD Negeri 06 and 18 of Nanggalo Lapai District of Padang City who suffered from asthma complaints totaling 32 people. The sampling technique uses saturated sampling, so that all populations are sampled. The asthma complaint instrument uses peak flow meter and nutritional status using anthopometry. Data were analyzed with ANOVA $2 \times 2$, and Tukey's further test if there was an interaction between swimming style and nutritional status at the significance level $\alpha=0.05$. Hypothesis testing results show, (1) there is a difference in effect between breaststroke and freestyle swimming against asthma complaints $(\mathrm{Qh}=3.05>\mathrm{Qt}=3.00)$, (2) there is an interaction between breaststroke and freestyle swimming with nutritional status $(\mathrm{Fh}=8.11>\mathrm{Ft}=4.20)$, (3) there is a difference between the groups that are given breaststroke and freestyle swimming treatments seen from the ideal nutritional status of asthma complaints $(\mathrm{Qh}=5.00>\mathrm{Qt}=3,26)$, and (4) there is no difference between the groups that were given treatment of breaststroke and freestyle swimming seen from the nutritional status not ideal for asthma complaints (Qh $=0.69<\mathrm{Qt}=3.26$ ).
\end{abstract}

Keywords: Chest Style Swimming, Freestyle Swimming, Nutrition Status, and Asthma Complaints

\section{INTRODUCTION}

One health problem that needs serious attention for countries in the world, especially Indonesia itself, is asthma. Asthma is a respiratory tract inflammation that can affect all age groups. Asthma is associated with narrowing of the airway that causes recurrent wheezing, shortness of breath, chest pressure until accompanied by coughing. Wheezing is the sound of breathing like the sound of whistles caused by the constriction of air flow during respiration.

The Association of Indonesian Lung Doctors (PDPI) on the commemoration of world asthma day on May 1, 2018 said, data from WHO currently there are around 300 million people who suffer from asthma worldwide. There are around 250,000 deaths caused by asthma attacks each year with the largest number in countries with a low-moderate economy. While basic health research in 2013, reported the prevalence of asthma in Indonesia was $4.5 \%$ of the population, with a cumulative number of asthma cases around 11,179,032. Asthma affects disability and premature death especially in children aged 10-14 years. Beyond this age, early mortality decreases but has more disability effects. At present, asthma is included in the 14 major diseases that cause disabilities throughout the world.

The high prevalence indicates that asthma management has not been successful. Various factors are the cause of the situation, namely the lack of knowledge about asthma, the implementation of management that has not been maximized, prevention efforts and counseling in the management of asthma that still needs to be improved. Given this, the best management of asthma must be done at an early stage with various preventative measures so that sufferers do not experience asthma attacks, especially to efforts to restore normal respiratory status as before. The risk factors for asthma that affect the development and expression of asthma consist of internal factors and external factors. Internal factors consist of Genetics, obesity, gender, age, physical activity, and strong or excessive emotional expression. While external factors include Occupational Irritant, viral infections in the respiratory tract, allergens, cigarette smoke, air pollution, drugs, and temperature changes related to 
seasonal changes or other geographical conditions (Suyono in Nursalam et al, 2009: 10 in Journal of Nurse Vol. 4 Number 1)

Asthma is an incurable but manageable disease. Asthma can be controlled by means of Pharmacologists (using drugs) and Non Pharmacologists (without drugs). Management is carried out in full, not only by providing Pharmacological therapy, but also using NonPharmacological therapy, namely by controlling asthma symptoms (Sundaru, Wong, Schulte, Price, Gwin in Mardhiah et al, 2009: 117 in Idea Nursing Journal Vol II No 3).

Based on this opinion, the safest way to minimize the occurrence of asthma is by NonPharmacologists, one of which is to do sports. Exercise is a part of good management for asthmatics when it is adjusted to the characteristics of asthmatics. Exercise can improve the ability to breathe asthmatics so it is important to do asthma control (Ram, Robinson, Black, Picot in Mardhiah et al, 2009: 117 in Idea Nursing Journal Vol II No. 3). One of the sports in question is swimming which is done regularly in accordance with the characteristics of asthmatics. Swimming can make the body healthy because almost all the muscles of the body are used when swimming (feet, hands and head). In addition to making the body healthy, swimming also provides benefits for healing asthma, especially since the asthma sufferer is still young. Swimming sports itself is divided into 4 swimming styles namely, 1) freestyle, 2) breaststroke, 3) backstroke, and 4) butterfly style.

Freestyle is alternating movement of the hand, meaning when one hand pulls the other hand in a state of rest. For leg movements, the activity is the same as the pull of the hand, which is taking turns to punch water and taking breath to the side of the body. The breaststroke is a cursory leg kick as well as frog leg movements when swimming. For hand pulls, the position of the hands remains on the surface of the water, hand pulls are circular to the water in the shape of a ball and breathing is carried forward. Back style is a swimming style that is different from other swimming styles. The difference is that the body facing the floor is the back and for the movements of the hands and feet the same as the freestyle swimming process. The butterfly style or the dolphin style is one of the swimming styles with the chest position facing the surface of the water. Both arms are simultaneously pressed down and moved outward before swinging forward. While both feet simultaneously kick up and down like a dolphin.

Based on observations and information made by the author at the State Elementary School in Nanggalo Lapai Subdistrict, Padang City, such as SD Negeri 06
Lapai village, SD Negeri 18 Lapai village, that there are 32 students who experience asthma complaints. Based on interviews conducted with the School Principal and Physical Education Sports and Health (PJOK) Public Elementary School 06 Kampung Lapai, one of them with Mr. Agus Yadi, S.Pd who said, that students who experience asthma complaints generally have limitations in carrying out physical activities, get tired quickly, lack of enthusiasm, less ideal posture (tend to be a bit thin), have below average academic value. In addition, children with asthma often become a mockery for their friends, it is not uncommon for students with asthma to feel uncomfortable hanging out with friends so they often do not go to school.

Based on the above problems, children who experience asthma complaints if left unchecked will affect their growth and development. Therefore, to find a way out for children who experience asthma complaints, the authors provide a solution through research on the influence of swimming style and nutritional status on asthma complaints. Swimming style in question, namely the breaststroke and freestyle seen from the nutritional status of children that is ideal or not ideal. That opinion, the need for a study to prove which swimming style is better to reduce asthma complaints seen from the nutritional status of children.

\section{MATERIALS AND METHODS}

The method used in this study is quasiexperimental (Quasy Experiment Design). According to Iskandar (2008: 64) said, "experimental research is research that requires researchers to manipulate and control one or more independent variables and observe the dependent variable, to see differences in accordance with the manipulation of the independent variable (Independent) or research that looks at the causal relationship to two or more variables by giving more treatment (Treatment) to the experimental group ".

This study will examine the causal relationship of the independent variable to the dependent variable and the Attribute / moderator variable, namely: swimming style as the independent variable, asthma complaints as the dependent variable and nutritional status as the Attribute / moderator variable.

The research design used is Factorial $2 \times 2$ By Level, where each independent variable is classified into 2 forms of swimming style (A), namely breaststroke swimming (A1) and freestyle swimming (A2), while the Attribute / moderator variables are classified in 2 forms of levels (B), namely ideal nutritional status (B1) and non-ideal nutritional status (B2).

This research was conducted in the swimming pool of the Faculty of Sport Science, Padang State University in July - August 2019. 
The population in this study were all students of SD Negeri 06 and 18 Nanggalo Lapai Subdistrict, Padang City, who suffered from asthma complaints totaling 32 people. Because the population is very limited, the determination of the sample in this study is based on Total Sampling or Saturated Sampling. According to Sugiyono (2011: 85) said, "Saturated sampling is a sampling technique when all members of the population are used as samples". Based on these considerations and the research design used, the number of samples in this study was 32 people.

Asthma measurements made using the Peak Flow Meter in units of L / sec. Measurement of nutritional status is done by Anthropometry tests which include weight and height based on the age group of 1617 years. Swimming given in this treatment is breaststroke and freestyle swimming with an intensity of $50 \%-70 \%$ of the maximum pulse rate. The treatments include heating, core and cooling.

Hypothesis testing is done by using Analysis of Variance (ANOVA) By Level $2 \times 2$. Before the analysis is carried out, first some testing of the analysis requirements is carried out, namely the normality test and the homogeneity of the data. If the Analysis of Variance results show the main effect (Main Effect) between the independent variables on the dependent variable and the interaction (Simple Effect) of the independent variables on the dependent variable, then proceed with the Tukey test as a further test to determine which groups have better results on asthma complaints at the significance level $\alpha=0.05$.

\section{RESULTS AND DISCUSSION}

Based on testing the first hypothesis, that there is a difference in effect between breaststroke and freestyle swimming on asthma complaints of elementary school students in Nanggalo Lapai Subdistrict, Padang City (Qhitung = 3.05> Qtable = 3.00). This means that both breaststroke and freestyle swimming treatments have differences in asthma complaints among elementary school students in Nanggalo Lapai Subdistrict, Padang City. If seen from the average difference, that the breaststroke swimming group is higher than the freestyle swimming group against asthma complaints of elementary school students of Nanggalo Lapai District of Padang, with the average breaststroke swimming $=$ 283.75 and freestyle swimming $=264.38$.

The second hypothesis testing, that there is an interaction between breaststroke and freestyle swimming with asthma complaints of elementary school students in Naggalo Lapai Subdistrict, Padang City with Fcount $=8.11>$ Ftable $=4.20$. In other words, it can be concluded that both breaststroke and freestyle swimming treatments are carried out appropriately, planned, continuously and in accordance with the basic principles of training, it will overcome the asthma complaints of elementary school students in the Naggalo Lapai District of Padang in terms of ideal nutritional status and not ideal.

The third hypothesis testing, that there is a difference between the groups given breaststroke and freestyle swimming treatments seen from the ideal nutritional status of asthma complaints of elementary school students in Nanggalo Lapai Subdistrict, Padang City (Qcount $=5.00>$ Qtable $=3.26)$. If viewed from the average compared, that the group given breaststroke swimming treatment with ideal nutritional status is better than the group given free style swimming treatment with ideal nutritional status, with average breaststroke swimming ideal nutritional status $=310.00$ and freestyle swimming ideal nutritional status $=$ 265.00.

The fourth hypothesis testing, that there is no difference between the groups given treatment of breaststroke and freestyle swimming seen from the nutritional status is not ideal against asthma complaints of elementary school students in Nanggalo Lapai Subdistrict, Padang City (Qcount $=0.69<$ Qtable $=$ 3.26). If it is seen from the average compared, that there is no significant difference between the treatment group with an ideal status between breaststroke and freestyle swimming, with the average breaststroke swimming nutritional status not ideal $=257.50$ and freestyle swimming nutritional status is not ideal $=263,75$. In other words, the two swimming styles can be used in dealing with asthma complaints for students who have not ideal nutritional status

Asthma is a respiratory tract inflammation that can affect all age groups. Asthma is associated with narrowing of the airway that causes recurrent wheezing, shortness of breath, chest pressure and coughing.

Exercise can improve the ability to breathe asthmatics so it is important to do it in controlling asthma.

One of the sports in question is swimming which is done regularly in accordance with the characteristics of asthmatics. This is according to the opinion of Wang \& Hung (2009) in the Journal of the Asian Pacific Society of Respirology Vol. 14 says, "swimming for asthmatic children program can improve some disease parameters (PEF and the severity of asthma). Swimming may be an effective non-pharmacological intervention for the child or adolescent with asthma. It can be concluded, that swimming programs for children with asthma can increase several disease parameters (PEF and asthma severity). Swimming is an effective NonPharmacological intervention for children or adolescents with asthma. 
Swimming can make the body healthy because almost all the muscles of the body are used when swimming (feet, hands and head). In addition to making the body healthy, swimming also provides benefits for healing asthma, especially since the asthma sufferer is still young. The horizontal position of the body during swimming changes the breathing path compared to other activities. This is because when swimming someone breathes in moist air, and humid air can reduce the risk of asthma attacks and swimming in the Horizontal position can loosen the mucus collected under the lungs. According to Rio (2010) in JornaldePediatria Vol. 86 No. 5 also said: "Swimming is a healthy exercise that is well tolerated by asthmatics because it induces less severe bronchoconstriction than other forms of physical activity. This protective effect of swimming is probably the result of the high humidity of inspired water at water level, which reduces respiratory water loss and possibly osmolarity of airways mucus. The horizontal position of the body during swimming might also play a role by altering the breathing pathway and producing less airway resistance than doing other sports. Swimming is thus frequently recommended to asthmatics as a safe and enjoyable mean to maintain their lung function, to increase their aerobic capacity and to improve their quality of life.

It can be concluded that swimming is a healthy sport that can be well tolerated by asthmatics because it causes less bronchoconstriction than other physical activities. The effect of swimming is the result of high inspired air humidity in water which reduces respiratory loss and possibly mucous osmolarity of the airways. The horizontal position of the body during swimming plays a role by changing the respiratory pathway. Thus, it produces less airway resistance than other sports. Therefore, swimming is often recommended for asthmatics as a safe and pleasant way to maintain the lung function of asthmatics as well as increase aerobic capacity and improve their quality of life.

Swimming style itself consists of several kinds of styles including, breaststroke, freestyle, backstroke and butterfly style. In this study conducted with two forms of treatment that have the same goal for asthma complaints, namely breaststroke and freestyle swimming. Both breaststroke and freestyle swimming have different practices, but have the same purpose because they both contribute to asthma complaints.

Foot kick movements in the breaststroke swimming at a glance as well as frog leg movements when swimming. For hand pulls, the position of the hands remains on the surface of the water, hand pulls are circular against the ball-shaped water and breathing is carried forward. Common swimmers do breaststroke by doing symmetrical limbs and arms. Breathing is done after beginning with the stroke of the arm. Body position on the breaststroke is in the water. Both palms together and push simultaneously forward then make a stroke inward so that the two palms meet again. Breaststroke swimming must be done in good, synergistic way between legs, arms and a combination of other limbs.

Freestyle swimming is the fastest style of all swimming styles and one of the first styles that must be taught to beginner swimmers. Implementation of freestyle swimming is by pedaling your arms so that they can move forward sequentially accompanied by continuous leg kicks. The horizontal position of the swimmer's body makes it easier for the swimmer to take a breath to one side after the stroke of the arm. According to Nenggala (2006) said, free style (crawl) is swimming with the chest position facing the surface of the water. According to Thomas (2007: 111), freestyle is a style that uses the movement of the hand swinging over the surface of the water, this style is also the meaning of the crawl style. Crawling style swimming is the fastest style among the three other styles (butterfly, chest and back).

In addition to swimming styles that have an effect on asthma complaints, another factor that determines is nutritional status. Consumption of nutrients that are not balanced or not in accordance with the needs of the body, let alone consume excess nutrients that cause a person to be obese so that it has a negative impact on health and asthma risk factors.

Nutritional status in this study is categorized into ideal and not ideal nutritional status. According to Djoko (2006: 2) said, "More broadly, nutrition is defined as a process of organisms using normally consumed food through the process of digestion, absorption, transportation, storage, metabolism and expenditure of nutrients to maintain life, growth and normal function of organs the body and produces energy ". According to Sunita (2003: 3) said, "nutrition is a chemical bond that is needed by the body to carry out its functions, namely producing energy, building and maintaining tissues, and regulating life processes". According to Syafrizar and Wilda (2008: 3) said, "nutritional status is the state of the body as a result of food consumption and use of nutrients, which are distinguished between under nutritional status, normal and more".

Based on the description, it can be concluded that in handling asthma complaints by providing swimming, namely breaststroke and freestyle swimming. Furthermore, the swimming style is adjusted to the characteristics of asthma sufferers based on their nutritional status. In other words, there is an interaction between the style of swimming given by the nutritional 
status of elementary school students in the District of Naggalo Lapai, Padang City.

\section{CONCLUSIONS AND SUGGESTIONS}

\section{A. Conclusions}

Based on the results of data analysis, the results of hypothesis testing and the results of research discussions, it can be concluded that:

1. There is a difference in the effect between breaststroke and freestyle swimming on asthma complaints of elementary school students in Nanggalo Lapai Subdistrict, Padang City.

2. There is an interaction between breaststroke and freestyle swimming with nutritional status against asthma complaints of elementary school students of Nanggalo Lapai Subdistrict, Padang City.

3.There is a difference between the groups given the treatment of breaststroke and freestyle swimming seen from the ideal nutritional status of asthma complaints of elementary school students of Nanggalo Lapai District of Padang

4. There is no difference between the groups that are given the treatment of breaststroke and freestyle swimming as seen from the nutritional status not ideal for asthma complaints of elementary school students in Nanggalo Lapai Subdistrict, Padang.

\section{B. Suggestions}

Based on the conclusions that have been put forward, then some suggestions can be made as follows:

1. For children with asthma, it is advisable to choose swimming as an alternative to reduce asthma complaints, namely breaststroke and freestyle swimming based on their nutritional status.

2. For parents, it is recommended to choose swimming as an alternative to reduce asthma complaints, namely breaststroke and freestyle swimming based on the nutritional status of the child.

3 . Further researchers who are interested in conducting similar studies, are advised to involve other variables, more expanded research objects, and consider factors relating to asthma complaints.

\section{REFERENCES}

[1] Djoko Pekik Irianto. (2006). Panduan Gizi Lengkap, Keluarga dan Olahragawan. Yogyakarta: C.V Andi OFFSET.

[2] Iskandar. (2008). Metodologi Penelitian Pendidikan Sosial (Kuantitatif dan Kualitatif). Jakarta: Gaung Persada Press (GP Press).

[3] Mardhiah. (2009). Efektivitas Olahraga Pernapasan tehadap Penurunan Gejala Asma pada Penderita Asma di Lembaga Seni Pernapasan Satria Nusantara Cabang Medan. Idea Nursing Journal Vol. II (3). 117-126. ISSN: 2087-2879.

[4] Nenggala, A. K. (2006). Pendidikan Jasmani, Olahraga, dan Kesehatan. Bandung: PT. Grafindo Media Pratama.

[5] Nursalam, dkk. (2009). Faktor Risiko Asma dan Perilaku Pencegahan Berhubungan dengan Tingkat Kontrol Penyakit Asma. Jurnal Ners Vol. 4 (1). 9 18.

[6] Perhimpunan Dokter Paru Indonesia dalam Rangka Peringatan Hari Asma Sedunia 2018. Diakses pada tanggal 29 Januari 2019 melalui www.klikpdpi.com.

[7] Rio J. (2010). Asthma and Swimming: Weighing the Benefits and the Risks. Jornal de Pediatria Vol. 86 (5). Print Version ISSN: 0021-7557. http://dx.doi.org/10.1590/S00217557201000050000 2

[8] Sugiyono. (2011). Metode Penelitian Kuantitatif, Kualitatif dan $R \& D$. Bandung: CV AlFABETA.

[9] Sunita Almatsier. (2003). Prinsip Dasar Ilmu Gizi. Jakarta: PT Gramedia Pustaka Utama.

[10] Syafrizar dan Wilda Welis. (2008). Ilmu Gizi. Padang: FIK UNP.

[11] Thomas, G. David. (2007). Renang Tingkat Pemula. Terj: Alfons. Jakarta: PT Raja Grafindo Persada.

[12] Wang, J.S \& Hung, W.P. (2009). The Effects of a Swimming Intervention for Children with Asthma. Journal Asian Pacific Society of Respirology Vol. 14. 838-842. DOI: $10.1111 / \mathrm{j} .1440$ 1843.2009.01567. 